\title{
Asymptomatic persistent non-virus non-alcohol related elevation of aminotransferase levels: a rare case and review of the literature
}

\author{
Virüs ve alkol ilişkili olmayan asemptomatik, persistan aminotransferaz düzeylerinin yüksekliği: \\ nadir bir vaka ve literatürün özeti
}

Gokhan TAZEGUL, Neslihan GUNES, Mete AKIN, Gulsum Ozlem ELPEK, Adil BOZ

\begin{abstract}
Alanine aminotransferase (ALT) and aspartate aminotransferase (AST) are found in the liver in their highest concentrations. Two most common causes of asymptomatic transaminase elevation are viral infections and alcohol intake. Persistent non-viral nonalcohol related elevation of aminotransferases indicates that one or both aminotransferase levels exceed the upper reference limit for a period of at least 4 weeks. Causes are classified as hepatic; such as steatosis, autoimmune hepatitis, Wilson's disease, hemachromatosis, and nonhepatic; such as celiac disease, myopathy and hyperthyroidism. Drug use and substance abuse may also cause an increase in aminotransferase levels. Here, we report a fifty-eight-year old female patient who had asymptomatic non-viral non-alcohol related aminotransferase elevation for a year incidentally diagnosed with malignant infiltration of the liver. It should be noted that, malignant infiltration of the liver may also be a rare cause of asymptomatic persistent elevation of transaminases. Such cases, especially with suspected malignancy should be evaluated in terms of this condition.
\end{abstract}

Keywords: Aspartate aminotransferase, Alanine aminotransferase, Asymptomatic diseases, Incidental findings

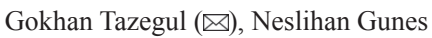

Department of Internal Medicine, School of Medicine, Akdeniz University, Antalya, Turkey

e-mail:gokhan.tazegul@yahoo.com

Mete Akin

Sub-department of Gastroenterology, Department of Internal Medicine, School of Medicine, Akdeniz University, Antalya, Turkey

Gulsum Ozlem Elpek

Department of Pathology, School of Medicine, Akdeniz University, Antalya, Turkey

Adil Boz

Department of Nuclear Medicine, School of Medicine, Akdeniz University, Antalya, Turkey

Submitted/Gönderme: 23.05.2016

Accepted/Kabul: 15.08.2016
ÖZ

Alanin aminotransferaz (ALT) ve aspartat aminotransferaz (AST) en yüksek konsantrasyonlarda karaciğerde bulunur. Asemptomatik transaminaz yüksekliğinin en sik iki sebebi viral enfeksiyonlar ve alkol kullanımıdır. Virüs ve alkol ilişkisi olmadan persistan aminotransferans yüksekliği, transaminazların biri veya ikisinin üst referans değerini en az 4 hafta aşması olarak tanımlanır. $\mathrm{Bu}$ yüksekliğe, steatoz, otoimmün hepatit, Wilson hastalığ1, hemokromatoz gibi hepatik kaynaklı nedenler ve çölyak hastalığı, miyopati ve hipertiroidizm gibi hepatik olmayan nedenler sebep olabilir. İlaç kullanımı ve uyuşturucu madde kullanımı da aminotransferaz yüksekliğine sebep olabilir. Bu vakada elli sekiz yaşında kadın bir hasta sunmaktayız. Hastanın virus ve alkol ilişkisi olmadan 1 y1l süren aminotransferaz yüksekliği mevcut olup hasta insidental olarak malin karaciğer infiltrasyonu tanısı almıştır. Karaciğerin malin infiltrasyonunun da persistan asemptomatik transaminaz yüksekliğine sebep olabileceği unutulmamalıdır. $\mathrm{Bu}$ tarz hastalarda, özellikle malignite şüphesi olan vakalar bu yönden de değerlendirilmelidir.

Anahtar kelimeler: Aspartat aminotransferaz, Alanin aminotransferaz, Asemptomatik hastalık, Rastlantısal bulgular

\section{Introduction}

Alanine aminotransferase (ALT) and aspartate aminotransferase (AST) enzymes are found in the liver in their highest concentrations. Both enzymes are released when the liver cell membrane is damaged and ALT is more specific to liver injury [1]. Two most common causes of asymptomatic transaminase elevation are viral infections and alcohol intake [1]. Persistent non-virus non-alcohol related aminotransferase elevation indicates that one or both aminotransferase levels exceed the upper reference limit for at least 4 weeks. Prevalence of this condition in Italy and United States is around 3-5\% [2]. Causes of persistent non- 
viral non-hepatic aminotransferase elevation are classified as hepatic causes, apart from alcohol intake and viral infections, such as steatosis, autoimmune hepatitis, Wilson's disease, hemachromatosis; and nonhepatic causes such as celiac disease, myopathy and hyperthyroidism $[1,3]$. Drugs, substance abuse and herbal medications may also cause an increase in liver enzymes, such as acetaminophen use [1,4]. However, a minor elevation of AST and ALT (less than twice the normal value) may be of no clinical importance and may not even be abnormal [1]. Here, we report a rare case of asymptomatic non-viral non-alcohol related liver enzyme elevation incidentally diagnosed with malignant infiltration of the liver.

\section{Case Report}

A fifty-eight-year old female patient who had asymptomatic AST and ALT elevation was referred to Gastroenterology outpatient clinic by her family physician. She was asymptomatic apart from mild occasional pain in her abdomen, arms and legs. Her family physician advised lifestyle modifications such as diet and exercise, however, significant improvement was not observed in one year. She had no drug or alcohol use. She had previously undergone total hysterectomy and bilateral oophorectomy due to excessive bleeding of the uterine myomas. She states that her mother had undergone hysterectomy from a benign pathology, and two of her uncles passed away from lung carcinomas. Her physical examination was normal. Laboratory results were: Hemoglobin:9.7 g/dl, Mean Corpuscular Volume (MCV): $67 \mathrm{fL}$, leukocytes: 6510/mm3, neutrophils: 3660/ mm3, platelets: 279.000/mm3, ALT: $91 \mathrm{U} / \mathrm{L}$ AST: $66 \mathrm{U} / \mathrm{L}$, gamma-glutamyl transpeptidase (GGT): $53 \mathrm{U} / \mathrm{L}$, alkaline phosphatase (ALP): $111 \mathrm{U} / \mathrm{L}$, lactate dehydrogenase (LDH): $178 \mathrm{U} / \mathrm{L}$, total bilirubin: $0.36 \mathrm{mg} / \mathrm{dL}$ direct bilirubin: $0.1 \mathrm{mg} / \mathrm{dL}$, albumin: $4.27 \mathrm{~g} / \mathrm{dL}$ PT: 11.8 seconds, aPTT: 24.4 seconds, INR: 1.03, TSH: $1.06 \mathrm{uIU} / \mathrm{ml}$, fT4: 1.04 $\mathrm{ng} / \mathrm{dl}$ and ferritin: $5.64 \mathrm{ng} / \mathrm{ml}$. A work-up for persistent aminotransferase elevation was planned. Hepatitis B and $\mathrm{C}, \mathrm{HIV}, \mathrm{EBV}, \mathrm{CMV}$ and HSV serologies were negative. ANA was 1/100 weak granular positive, ENA assay was negative, ANCA, Anti-LKM and ASMA were negative as well. Plasma seruloplasmin, alpha-1 antitrypsin and 24-hour urinary copper excretion were within normal range. Antiendomysium IgA and IgG were both negative. Abdominal ultrasonography (USG) revealed a mild hepatomegaly with normal parencyhmal echo and no local masses. Hepatic Doppler USG was normal.
A liver biopsy was carried out to diagnose the cause of persistent elevation of liver enzymes. Biopsy revealed malignant infiltration of liver with vimentin, CK7, 18 and 19 positive cells (Figure 1). No primary focus was diagnosed from the biopsy. Pathology advised genitourinary check-up for primary tumor. Upper gastrointestinal endoscopy and colonoscopy were normal. Thorax and abdomen computed tomographies (CT) were normal. Gynecological examination, urological examination, mammography and breast ultrasound were normal. Carcinoembryogenic antigen, Ca 15-3, Ca199 and CA125 were within normal range. Positron emission tomography (PET)-CT revealed metastatic focuses in hepatic segments 2 and 4 (SUVmax: 7), a focus on anterior wall of gallbladder (SUVmax: 6), periportal hypermetabolic lymph nodes (SUVmax: 6), a focus on distal choledochus (SUVmax: 6) and multiple gastric and duodenal focuses (SUVmax: 8) (Figure 2). Patient was diagnosed as metastatic malignant epithelial tumor with unknown primary origin and was referred to Oncology Department. Carboplatin-paclitaxel chemotherapy was planned.

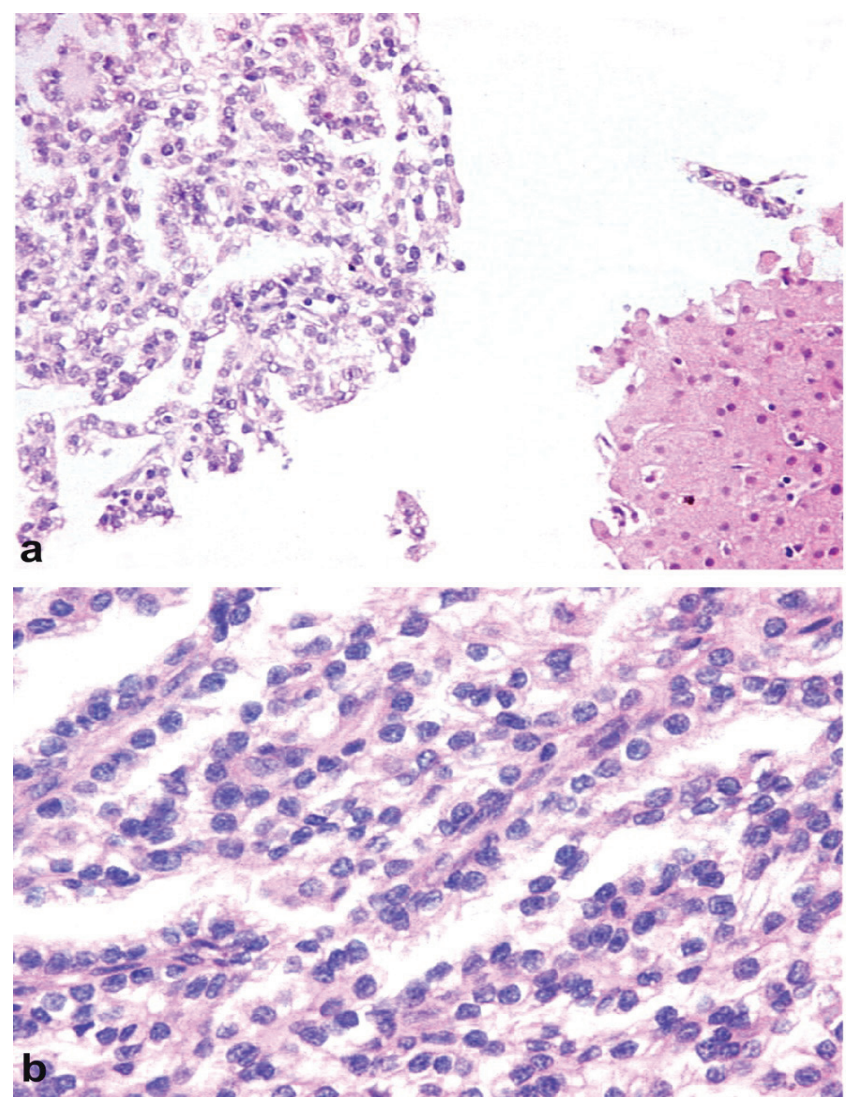

Figure 1: (a) Serial sections from tissue specimens reveal liver (bottom right) in the vicinity of tumor tissue (top left) (H\&E, x200) (b) High magnification of tumor shows it is composed of trabecule and gland forming atypical cells (H\&E, x400) 


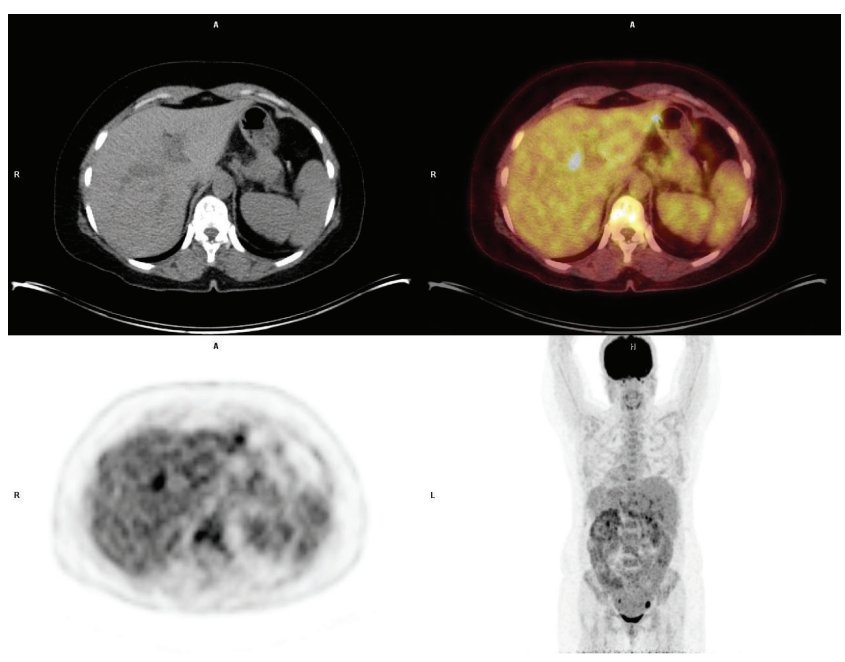

Figure 2: Metastatic focuses in hepatic segments 2 and 4 (SUVmax: 7), a focus on anterior wall of gallbladder (SUVmax: 6 , reported as primary?, metastatis?), periportal hypermetabolic lymph nodes (SUVmax: 6, reported as metastasis?), a focus on distal choledochus (SUVmax: 6, reported as malignancy?) and multiple gastric and duodenal focuses (SUVmax: 8) can be seen on PET-CT.

\section{Discussion}

Asymptomatic non-virus non-alcohol related liver enzyme elevation is a very common clinical picture. Rochling [5] reported that $6 \%$ of asymptomatic people may have abnormal liver enzyme levels whereas overall prevalence of liver disease is only $1 \%$. Giboney [3] states up to $4 \%$ of the asymptomatic population may have elevated serum liver tests. A follow up study on patients who had mild elevation of liver enzymes showed 38\% spontaneous remission [6]. These findings state that not all asymptomatic liver enzyme elevations are pathologic. Apart from alcohol intake and viral infections, steatosis and medications are common causes of asymptomatic transaminase elevation, whereas hemochromatosis, autoimmune hepatitis, Wilson's disease and Celiac's disease may cause asymptomatic transaminase elevations as well $[1,3]$. Drugs such as synthetic penicillins, ciprofloxacin, phenytoin, carbamazepine, non-steroidal antiinflammatory drugs and acetaminophen may cause mild elevations of transaminases $[1,4]$. Some herbs and substances of abuse may also cause elevation of transaminases, however our patient did not use such substances.

The adapted form of American Gastroenterological Association (AGA) statement by Giboney [3] suggests that if a patient has less than five times elevated transaminases, first line tests should be prothrombin time, albumin, complete blood count, hepatitis A, B, and C serologies, serum iron, total iron binding capacity and ferritin. Patients with negative serologies and without hepatic decompensation should modify their lifestyles: discontinue alcohol use, stop taking hepatotoxic medications and lose weight. If aminotransferase levels are still elevated at the six month follow up, further testing of antinuclear antibodies, antismooth-muscle antibody, ceruloplasmin, alpha 1-antitrypsin, antigliadin, and antiendomysial antibody for rare causes of aminotransferase elevation are warranted. According to the AGA, decision to perform a liver biopsy needs to be made on an individual basis, taking into consideration the patient's age, lifestyle, liver chemistry abnormalities, desire for prognostic information, and associated comorbid conditions $[7,8]$. Our patient had all first line tests, she tried life style modification without success and then was referred to our clinic. Further tests were also negative and a liver biopsy was carried out on patient's consent.

Liver biopsy may not change the prognosis or diagnosis in these patients. A study of 149 asymptomatic patients with elevated ALT levels who underwent liver biopsy showed $56 \%$ of these patients had fatty liver disease, $20 \%$ had nonviral hepatitis (non-A, non-B), $11 \%$ had changes related to alcohol use, $3 \%$ had hepatitis B, $8 \%$ had other causes, and in $2 \%$, no cause was identified [9]. Another study assessed 1124 consecutive patients who were referred for chronic elevations in aminotransferase levels. Eighty-one of these patients had no definable cause and underwent liver biopsies. Out of these 81, 41 had steatosis, 26 had steatohepatitis, 4 had fibrosis, 2 had cirrhosis and 8 had normal histological findings. Patients with histological evidence of fibrosis and cirrhosis also had evidence of fatty metamorphosis. None of the biopsies yielded a specific diagnosis except showing steatosis and steatohepatitis [10].

We present a patient who had asymptomatic mild elevation of transaminases over a year. After most common pathologies were ruled out, a liver biopsy was carried out. Although current literature states that liver biopsy almost always does not yield any specific diagnosis and does not change prognosis in these patients, our biopsy showed malignant infiltration of the liver. USG and CT of the abdomen failed to detect liver involvement while PETCT revealed metastatic focuses in our case. It is not clear that, whether the liver biopsy was taken incidentally from metastatic focuses, which were detected on PET-CT, or there was a diffuse involvement in the liver. We did not perform a repeat biopsy.

Radiologically occult liver metastasis usually occurs as diffuse malignant infiltration of the liver. This has been 
reported in the literature secondary to metastases from breast and lung carcinomas, prostate and urothelial carciomas, carcinomas of unknown primary origin and hematologic malignancies such as Hodgkin and Non-Hodgkin lymphomas [11-16]. USG and CT scans of the liver were reported as normal in almost all of these reported cases as it was in our case. Although, PET-CT revealed a suspected primary focus in gallbladder and gastric focuses in our case, urological and endoscopic examinations were normal and we could not find a clear primary origin. In addition, most of the reported cases presented with fulminant hepatic failure and showed poor prognosis, however, our case was asymptomatic and manifested with chronic persistent mild elevation of transaminases.

In conclusion, it should be noted that, malignant infiltration of the liver may also be a rare cause of persistent asymptomatic mild elevation of transaminases. Such cases, especially with suspected malignancy symptoms, should be thoroughly evaluated in terms of this condition.

\section{References}

1. Pratt DS, Kaplan MM. Evaluation of abnormal liverenzyme results in asymptomatic patients. $\mathrm{N}$ Engl $\mathrm{J}$ Med 2000;342:1266-1271.

2. Morisco F, Pagliaro L, Caporaso N, Bianco E, Sagliocca L, Fargion S, Smedile A, Salvagnini M, Mele A; University of Naples Federico II, Italy. Consensus recommendations for managing asymptomatic persistent non-virus non-alcohol related elevation of aminotransferase levels: suggestions for diagnostic procedures and monitoring. Dig Liver Dis. 2008;40:585-98. doi: 10.1016/j.dld.2008.02.003.

3. Giboney PT. Mildly elevated liver transaminase levels in the asymptomatic patient. Am Fam Physician 2005;71:1105-10.

4. Oh RC, Hustead TR. Causes and evaluation of mildly elevated liver transaminase levels. Am FAM Physician 2011;84:1003-8.

5. Rochling FA. EVALUATION of abnormal liver tests. Clin
Cornerstone 2001;3:1-12.

6. Sherwood P, Lyburn I, Brown S, Ryder S. How are abnormal results for liver function tests dealt with in primary care? Audit of yield and impact. BMJ 2001;322:2768.

7. Green RM, Flamm S. AGA technical review on the evaluation of liver chemistry tests. Gastroenterology 2002;123:1367-84.

8. American Gastroenterological Association. Medical position statement: evaluation of liver chemistry tests. Gastroenterology 2002;123:1364-6.

9. Hultcrantz R, Glaumann H, Lindberg G, Nilsson LH. Liver investigation in 149 asymptomatic patients with moderately elevated activities of serum aminotransferases. Scand J Gastroenterol 1986;21:109-13.

10. Daniel S, Ben-Menachem T, Vasudevan G, Ma CK, Blumenkehl M. Prospective evaluation of unexplained chronic liver transaminase abnormalities in asymptomatic and symptomatic patients. Am J Gastroenterol 1999;94:30104.

11. Hanamornroongruang S, Sangchay N. Acute liver failure associated with diffuse liver infiltration by metastatic breast carcinoma: A case report. Oncol Lett. 2013;5:1250-2. doi: 10.3892/ol.2013.1165

12. Simone C, Murphy M, Shifrin R, Zuluaga Toro T, Reisman D. Rapid liver enlargement and hepatic failure secondary to radiographic occult tumor invasion: two case reports and review of the literature. J Med Case Rep 2012;6:402. doi: 10.1186/1752-1947-6-402.

13. Allison KH, Fligner CL, Parks WT. Radiographically occult, diffuse intrasinusoidal hepatic metastases from primary breast carcinomas: a clinicopathologic study of 3 autopsy cases. Arch Pathol Lab Med 2004;128:1418-23.

14. Alcalde M, Garcia-Diaz M, Pecellin J, et al. Acute liver failure due to diffuse intrasinusoidal metastases of urothelial carcinoma. Acta Gastroenterol Belg 1996;59:163-5.

15. Shakir FA, Madhoun M, Whorton J, Harty R. Metastatic prostatic carcinoma presenting as fulminant hepatic failure. South Med J 2008;101:1049-50. doi: 10.1097/ SMJ.0b013e31817c74c3

16. Rowbotham D, Wendon J, Williams R. Acute liver failure secondary to hepatic infiltration: a single centre experience of 18 cases. Gut 1998;42:576-80. 